\title{
NEW DIRECTIONS FOR MINORITY ENTERPRISE
}

\author{
SaMguer I. Doctors* and SHaron Lockwood $\dagger$
}

I

\section{The NeEd for New Directions}

Minority enterprise has historically been limited to primarily small retail establishments, personal service businesses, and small construction contractors. Despite the fact that minority groups constitute about seventeen per cent of our population, ${ }^{1}$ they own less than three per cent of the nation's businesses. ${ }^{2}$ Perhaps even more significant is the fact that these businesses control less than one-half per cent of the nation's business assets. ${ }^{3}$

Present programs for minority business development have emphasized loans, grants, and subsidies to small businesses primarily in retail services and construction areas. These businesses are often in crowded business sectors, small margin, lowgrowth potential areas such as gasoline service stations, barber shops, or small retail food markets and often serve an impoverished clientele. The historic failure rate for these types of businesses is quite high. ${ }^{4}$ Although data is scarce in this area, it appears that less than twenty per cent of all new small businesses survive their first five years. ${ }^{5}$ New minority businesses are even more vulnerable due to a lack of access to financial and technical resources. ${ }^{6}$ However, even those which do achieve

* Associate Professor of Management, Northwestern University Graduate School of Management, and Consultant to the National Advisory Council on Minority Business Enterprise (NACMBE) and Acting Associate Director, National Strategies and Goals Task Force; Editor of NACMBE Final Report.

† Economic Advisor to the National Advisory Council on Minority Business Enterprise.

The authors owe a debt of gratitude for assistance in the preparation of this paper to the following persons: Mr. George Aragon, Doctoral candidate, Harvard Business School, and Consultant to the NACMBE; Professor Frank Cassell, Professor of Industrial Relations, Northwestern University Graduate School of Management, and Consultant to the NACMBE; Miss Anita Henry, Candidate for the J.D. degree, Yale Law School, and Research Assistant to the NACMBE.

1 "Minority group" is defined for this paper to include only blacks, persons of Spanish-speaking ancestry, and American Indians.

${ }^{3}$ Office of Planning, Research, and Analysis of the Small Business Administration, Distribution of Minority-Owned Businesses, June, I969, at I (unpublished report). Theodore Cross has estimated that there are only a dozen black businesses in Manhattan which employ ten or more people. T. Cross, BLACK CAPITAIISM 60 (rg69).

${ }^{3}$ Distribution of Minority-Owned Businesses, supra note 2.

'See generally The President's Tasr Force Report on IMproving the Prospects of SMail Business $21-27(1970)$.

'Id. See also Roberts, Entrepreneurship and Technology, in Factors IN THE Transfer of Technology 219, $224-25$ (D. Marquis \& W. Gruber Eds. I969); A. Parpus, The Small Business Administration 5 $\mathrm{x}-55$ (1968). Of course most business discontinuances are not outright bankruptcies; still for every five new businesses started, another 3.5 go out of business each year.

${ }^{\circ}$ One estimate of minority business failure or discontinuances may be obtained by examining the relative default rates on SBA loans between non-minority and minority borrowers. Parris estimates that minority defaults were running ten to twenty times the rate of non-minority defaults (three per cent). A. PArris, supra note 5, at rr6. However, this estimate is based solely on the Economic Opportunity 
some modest degree of success are unlikely to achieve growth rates that would create high leverage business opportunities for very many members of the minority community. Moreover, these businesses often lock their owners into a life of long hours, and hard, non-stimulating work with little or no opportunity to branch out of the pattern of marginal growth opportunity.

Surveys of existing minority businesses indicate that there are very few with gross sales as large as one million dollars a year and none which approaches the size of the 500 largest white owned and controlled corporations. ${ }^{7}$ Nor do we find minority group members in positions of control or decision making in the large American corporations where they could gain the managerial experience to start companies which might grow to a place among the largest American businesses.

Other data indicate that minority business development, although receiving some stimulus from present public and private efforts, still shows no signs of the exponential growth rate needed to catch up with white business development and may in fact be falling relatively farther behind. We have raised the expectations of our minority groups for examples of such exponential growth but have neither formed nor created models capable of achieving these catchup growth rates.

As may be seen from the sample of minority businesses presented in Tables I and II, the minority entrepreneur tends to enter the more marginal types of businesses. Table I indicates that a disproportionate number of minority entrepreneurs are in the personal service area. While some facets of the service industries are higher growth areas, the more disaggregated data in Table II reveals that the minority entrepreneurs are not in these higher growth areas.

Little effort has been made to guide the minority entrepreneur to more lucrative business opportunities. Most government and non-government programs are grounded in the concept that simply establishing a minority member in a business is sufficient. This reasoning requires serious reconsideration. If minority businessmen are not guided to the higher growth areas, their businesses will not help the minority economy approach the national economy.

To lift minority enterprise from the ghetto and the barrio to which it has been consigned, a strategic thrust must now aim at providing opportunities for higher growth potential models of minority enterprise. These model businesses should be

Loan (EOL) program through I 968 and a more recent analysis of the SBA minority loan program indicates that overall default rates are likely to be lower than was previously true for the EOL program. See Small Business Administration, Evaluation of the Minority Enterprise Program, Jan., I97r (unpublished report). For a discussion of the difficulties in running a ghetto-based small business, see T. CRoss, supra note 2 , at 2I-30.

T See Distribution of Minority Enterprise, supra note 2. A recent Office of Economic Opportunity (OEO) survey of larger minority businesses attempted to identify minority businesses with annual sales in excess of $\$ 500,000$, and which showed a profit for the last two years. The largest business so identified was Johnson Publications, Inc., with annual sales in 1969 of about $\$ 33$ million, and this was three times the size of the next largest minority business, Johnson Products, Inc. About Ioo companies were included in this study; of these, 24 met the sales and profitability criteria. OEO memo from Paul London and Susan Davis to Theodore Cross, Minority Business Successes, May 19, I970. The smallest company listed among the Fortune 500 had sales of $\$ 162$ million in I969. The Fortune Directory, May, r970, at 23. 
TABLE I

Distributton of Minority and Non-Minority Business Enterprises

\begin{tabular}{|c|c|c|}
\hline & Minority Owned & Non-Minority Owned \\
\hline 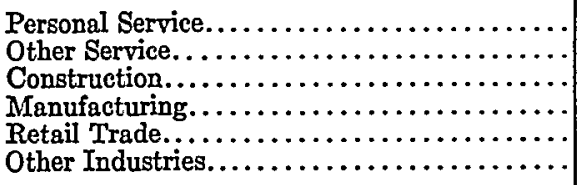 & $\begin{array}{r}26.9 \\
15.1 \\
10.8 \\
2.2 \\
34.0 \\
11.0\end{array}$ & $\begin{array}{r}7.3 \\
20.3 \\
9.0 \\
7.9 \\
34.9 \\
21.6\end{array}$ \\
\hline All Other Industries............... & 100.0 & 100.0 \\
\hline
\end{tabular}

Source: Office of Planning, Research, and Analysis of the Small Business Administration, Distribution of Minority-Owred Busiress, June, 1969 , at 7 (unpublished report).

TABLE II

Categortes and Types of Black Business Enterprises

\begin{tabular}{|c|c|c|}
\hline Category & Number & Percentage \\
\hline 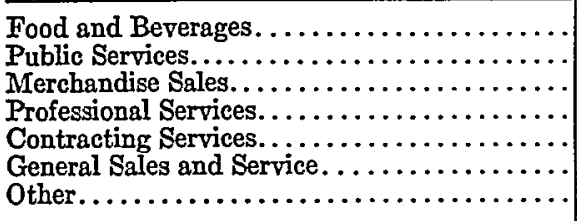 & $\begin{array}{r}173 \\
101 \\
37 \\
35 \\
31 \\
169 \\
18\end{array}$ & $\begin{array}{r}30.7 \\
17.9 \\
6.5 \\
6.2 \\
5.5 \\
30.0 \\
3.2\end{array}$ \\
\hline TOTAI........ & $\overline{564}$ & 100.0 \\
\hline
\end{tabular}

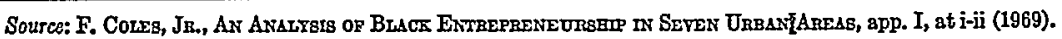

capable of growing at the rate of ten to twenty per cent or more per year over the next five to ten year period. ${ }^{8}$ Such new enterprises will help meet rapidly rising expectations, provide for true upward mobility, stimulate capital formation, and provide attractive alternative routes for minority employment and provide success models for future programs. ${ }^{9}$

\footnotetext{
"The 216 Boston "route I28" spinoff companies studied by Edward Roberts and his colleagues had an annual five year growth rate of over 20 per cent per year. Roberts, supra note 5, at 225-27. The same type of growth rate was exhibited by a sample of $x_{3}$ companies used in a technology transfer study by the author. S. Doctors, The NASA Transfer Program: An Analysis (to be published about November I97I by Praeger). Much of the growth achieved by these companies has been made possible through the creation of a protected market by the federal government. Clearly this same federal government power could be used in the development of minority enterprise as it has been used to develop an aerospace industry.

${ }^{\circ}$ It is assumed, contrary to Andrew Brimmer, that the promotion of minority enterprise does not have the sole objective of providing employment for larger numbers of blacks. It is assumed that the creation of numbers of viable minority-owned enterprises may serve a number of other socio-economic objectives. It is also assumed that minority economic development requires a holistic approach to such development, including the parallel provision of improved employment, business, educational, and health care opportunities. Just as in the non-minority community, it is the synergistic interaction of a variety of factors which will result in significant development. See A. Brimmer \& H. Terrell, The Economic Potential of Black Capitalism, Dec. 29, I969 (paper presented before the 82nd Annual Meeting of the American Economic Association).
} 
Many new opportunities for minority entrepreneurs to obtain financial assistance have become available, not only in the Small Business Administration, but also in the Department of Commerce, the Office of Economic Opportunity, and in the private sector. New and expanded business opportunities capable of leveraging these expanding sources of capital funds must be provided to stimulate the creation of enterprises which can multiply their initial investments many times over.

Much of this development should occur in higher growth industries, although medium- and low-profit, low-growth potential industries should not be completely excluded. They may provide needed goods and services for the community, and serve to keep a larger amount of capital within the ghettos and barrios. Medium or lower growth potential businesses may also provide some training opportunities for a number of potential minority entrepreneurs and managers. Thus, this latter type of business may also play some role in long term economic development of minority communities.

Today's minority entrepreneur is finally ready to gain a more advantageous position in the economy. Higher minority educational levels, increased minority incomes, a wider range of business opportunities, the changing attitude of public and private institutions toward minority entrepreneurs, and an attitudinal change in the minority community towards business as a career, have combined to bring about an environment which can fit the minority entrepreneur for entering higher growth industries. The educational level of minorities appears to be improving more rapidly than that of the population as a whole. As entrepreneurs are usually drawn not from the most disadvantaged groups, but from the middle classes, ${ }^{10}$ this increase in educational level will undoubtedly be reflected in a growing pool of potential and actual entrepreneurs (Table III). The rapidly increasing family income of minority groups (Table IV) is reflected in the growing purchasing power in the minority community. This increased purchasing power can support a larger number of minority businesses and a wider range of products and services. Thus, an increased range of business opportunities should be available within the minority community. The increased educational level and the extensive needs of the general public in the areas of goods and services should increase the range of business opportunities for the minority entrepreneur.

There has been an increasing concentration of the minority community in the urban area during the decade of the fifties and the sixties (Table V). This increasing concentration in the urban areas may, on the one hand, help consolidate purchasing power to the advantage of the minority entrepreneur. On the other hand, with the move to the suburbs by the non-minority middle class, much of the capital and markets needed for economic development is no longer available in the central city.

\footnotetext{
${ }^{10}$ This idea is suggested by the work of Frazier, McClelland, and Roberts. E. Frazien, BLAck Bourgeotsie (I968); D. McClelinand \& D. Winter, Mottvattang Econonac Achinvement (I969); Roberts, stipra note 5 .
} 
TABLE III

Per Cent Distrubution by Years of School Completed for Persons 20 Years Old and Over, by Age, ig69

\begin{tabular}{|c|c|c|c|c|}
\hline & $\begin{array}{l}\text { Iess than } \\
4 \text { years } \\
\text { High School }\end{array}$ & $\begin{array}{l}\text { Eigh } \\
\text { school } \\
4 \text { years }\end{array}$ & $\begin{array}{l}\text { College } \\
1 \text { year } \\
\text { or more }\end{array}$ & $\begin{array}{c}\text { Median Years } \\
\text { of school } \\
\text { completed }\end{array}$ \\
\hline 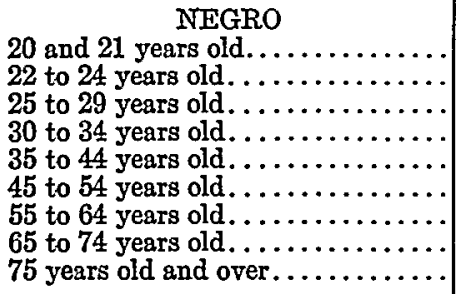 & $\begin{array}{l}42.1 \\
43.9 \\
44.3 \\
49.8 \\
62.8 \\
70.8 \\
85.2 \\
89.7 \\
92.4\end{array}$ & $\begin{array}{r}36.6 \\
37.1 \\
40.1 \\
36.7 \\
26.8 \\
18.9 \\
8.7 \\
5.5 \\
4.1\end{array}$ & $\begin{array}{r}21.2 \\
19.1 \\
15.7 \\
13.5 \\
10.5 \\
10.3 \\
6.2 \\
4.9 \\
3.5\end{array}$ & $\begin{array}{r}12.2 \\
12.2 \\
12.1 \\
12.0 \\
10.6 \\
9.1 \\
7.6 \\
6.1 \\
5.2\end{array}$ \\
\hline 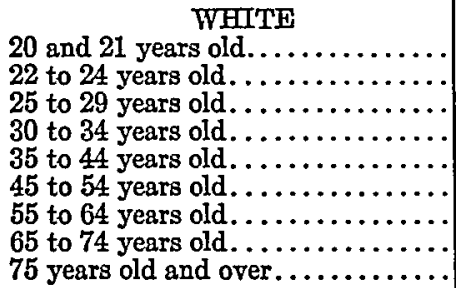 & $\begin{array}{l}18.1 \\
19.6 \\
23.0 \\
27.3 \\
33.9 \\
40.7 \\
55.2 \\
67.6 \\
75.1\end{array}$ & $\begin{array}{l}41.6 \\
44.8 \\
44.8 \\
44.9 \\
41.0 \\
39.3 \\
27.5 \\
18.9 \\
13.8\end{array}$ & $\begin{array}{l}40.1 \\
35.7 \\
32.1 \\
27.6 \\
25.1 \\
20.0 \\
17.3 \\
13.4 \\
11.1\end{array}$ & $\begin{array}{r}12.8 \\
12.7 \\
12.6 \\
12.5 \\
12.4 \\
12.2 \\
10.9 \\
8.9 \\
8.5\end{array}$ \\
\hline
\end{tabular}

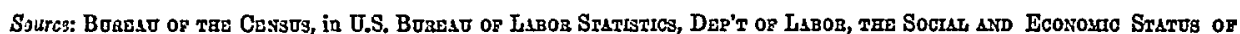
NEGzOES IN THe UNTTED STATES 50 (1970).

\section{TABLE IV}

Median Family Income in I968, and Negro Family Income, I965-Ig68, as a Per Cent of White, by Region

\begin{tabular}{|c|c|c|c|c|c|c|}
\hline & \multicolumn{2}{|c|}{$\begin{array}{l}\text { Median family } \\
\text { income, } 1968\end{array}$} & \multicolumn{4}{|c|}{$\begin{array}{l}\text { Negro income as a per cent } \\
\text { of white }\end{array}$} \\
\hline & Negro & White & 1965 & 1966 & 1967 & 1968 \\
\hline 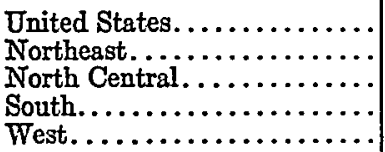 & $\begin{array}{r}\$ 5,359 \\
6,460 \\
6,910 \\
4,278 \\
7,506\end{array}$ & $\begin{array}{r}\$ 8,936 \\
9,318 \\
9,259 \\
7,963 \\
9,462\end{array}$ & $\begin{array}{l}54 \\
64 \\
74 \\
49 \\
69\end{array}$ & $\begin{array}{l}58 \\
68 \\
74 \\
50 \\
72\end{array}$ & $\begin{array}{l}59 \\
66 \\
78 \\
54 \\
74\end{array}$ & $\begin{array}{l}60 \\
69 \\
75 \\
54 \\
80\end{array}$ \\
\hline
\end{tabular}

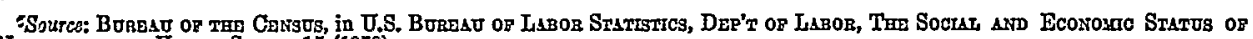
Neanoeg IN Tay UnTTED STATES 15 (1970).

One of the most interesting elements in today's minority enterprise climate is the changing attitude in the minority community toward the status of the entrepreneur. Heretofore, the ambitious black perceived the obstacles to a business career and often chose a career in the professions. He had access to professional education in black educational institutions and he had a captive clientele since white doctors, dentists, or lawyers frequently did not or would not provide these services to the 


\section{TABLE V}

Negroes as a Per Cent of Total Population by Location, Instde and Outside Metropolitan Areas, and by Size of Metropolitan Area, 1950, r960; and 1969

\begin{tabular}{|c|c|c|c|}
\hline & \multicolumn{3}{|c|}{ Per cent Negro } \\
\hline & 1950 & 1960 & 1969 \\
\hline 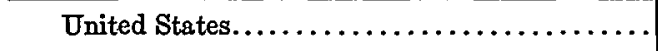 & 10 & 11 & 11 \\
\hline 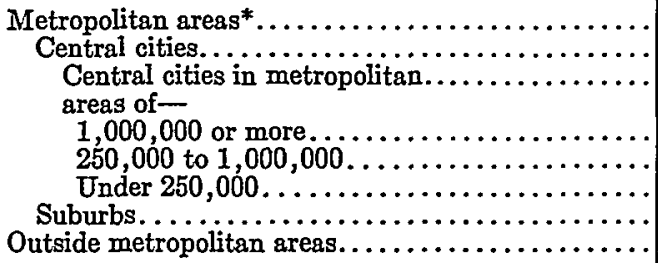 & $\begin{array}{r}9 \\
12 \\
13 \\
12 \\
12 \\
5 \\
11\end{array}$ & $\begin{array}{r}11 \\
17 \\
19 \\
15 \\
12 \\
5 \\
10\end{array}$ & $\begin{array}{r}12 \\
21 \\
\\
26 \\
18 \\
12 \\
5 \\
9\end{array}$ \\
\hline
\end{tabular}

* Population of the 212 SMSA's as defined in 1960.

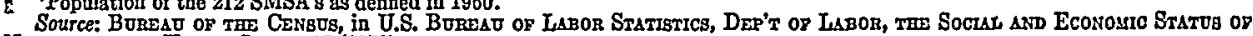
NEGROES IN TEE UNTTED STATES 15 (1970).

black population. ${ }^{11}$ Highly motivated blacks, unlike the highly motivated in other racial groups, were discouraged from entering business and were diverted to the professions. The black population valued the contribution of the black professional man, but tended to diminish the contribution of the black businessman. In fact, until recently it was considered prestigious in the black community to purchase name brands from non-minority enterprises. The goods of the black merchant were thought to be inferior, apparently for no reason other than that the proprietor was black. ${ }^{12}$

\section{II}

\section{Growth Potential Industries}

Minority enterprise opportunities should be developed which:

I) contribute to the capacity of the various minorities to take advantage of business opportunities beyond particular ethnic or racial markets;

2) have a capacity for growth and capital creation;

3) capitalize upon the skills and knowledge of all elements of the population;

4) promote areas of comparative advantage such as health care, job training, day care and communications in the minority community;

5) promote short and long-run community development objectives;

6) make effective use of government-created and protected markets, particularly in new, higher growth areas. ${ }^{13}$

\footnotetext{
${ }^{11}$ A recent survey of the graduates (346-r946 to 1969 ) of Atlanta University's (AU) School of Business Administration, indicated that most of their graduates, prior to 1968 , had entered non-business occupations. AU has produced over half of all the black M.B.A.'s in the period Ig08 to 1969.

${ }_{12}$ This is especially true for the black middle class. See E. Frazier, supra note 10.

${ }^{13}$ The core recommendations of the National Advisory Council on Minority Business Enterprise
} 
Economic indicators show where the potential for minority business lies. Real economic growth of the United States is expected to average 44 per cent per year, so that the Gross National Product (GNP) will increase from the third quarter 1970 level of 985.2 billion to almost 1.4 trillion dollars by $1980 .{ }^{14}$ With this increase, the consumption rate of nondurable goods is expected to decline from 62 per cent to 60 per cent during the period from 1967 to $1980 .{ }^{15}$ At the same time, increases in family formation, rising incomes, and replacement of old and substandard housing will push demand for new housing to 2.4 million units per year in the late 1970's. This factor will account for the rise in private domestic investment growth from the 1967 level of 15 per cent to over 16 per cent of the r 980 GNP. ${ }^{16}$

Expenditures on consumer durable goods will show the highest rate of growth, largely because of rising affluence. Between 1967 and 1980 , real disposable income per capita is projected to increase at an annual average of 3.I per cent, doubling the proportion of families with real incomes of $\$ 10,000$ or more from around 25 per cent of all consumer units to around $5^{\circ}$ per cent. Higher incomes, along with increased leisure time, will influence demands for recreation equipment, such as boats, motors, automobiles, televisions, pleasure aircraft, and sporting goods. There will also be large demands for household furnishings because of the large increase in the 25-34 age group..$^{17}$

Consumer spending for nondurable goods will continue to grow at a slower rate than total spending. By 1980 , Americans are expected to spend only $3^{8}$ per cent of total expenditures on consumer nondurables, compared to 44 per cent in 1967 and 55 per cent in 1968. A large share of the consumer nondurables will be for clothes, household supplies, gasoline and oil, drugs, personal grooming aids, and reading materials. Spending for food and beverages will decrease as a proportion of total nondurable expenditures. ${ }^{18}$

Statistical data from the Department of Commerce indicates that consumers will, for the first time in American history, spend more money on services-air travel, car rentals, beauty parlors, advertising and management consulting, life insurance, and so on-than for nondurable goods. Even though the prices for services have risen at a faster than average rate, services have proliferated and their coming preeminence will present a whole new set of opportunities and challenges. Major components within the services field will be housing, business expenditures, medical services, and education and research. ${ }^{19}$ These then are prime areas for minority enterprise to enter.

(NACMBE) placed stress on the need for greatly expanded training and educational opportunities and recommended the allocation of $\$ 160$ million over the next three years to assist materially in this area.

${ }^{14}$ Labor Department Forecast, November, 1970.

${ }^{15}$ Predicasts, April 20, 1970, at 3.

${ }^{10}$ Id.

${ }^{27} I d$.

${ }^{28}$ National Consumer Finance Association, Finance Facts Yearbook (1970).

${ }^{20}$ Sales Management-r970 Survey of Buying Power, June 10, 1970, at A-21. 
Using projections from the Bureau of Labor Statistics, an examination of output demand can be used to show a national trend in higher growth businesses. The data reveals obvious business opportunities in those industries with projected substantial increases in growth rate. These include the following industries: optical, ophthalmic, and photographic equipment; electric, gas, and sanitary services; business services; and office supplies. ${ }^{20}$

Industries for which the projected demand for ouput is expected to grow at medium high and increasing rates include the following:

nonferrous metal ores

new construction

household furniture manufacture

manufacture of other furniture and

fixtures

manufacture of paper and allied prod-

ucts, except containers

printing and publishing

manufacture of stone and clay products the wholesale and retail trade industry medical, educational services and nonprofit organizations

primary nonferrous metals manufacture manufacture of electrical industrial equipment and apparatus

manufacture of miscellaneous electrical machinery, equipment and supplies scientific and controlling instruments miscellaneous manufacturing hotels, personal and repair services, except automobile repair services

Some discretion must be used in evaluating those industries which will show high rates of growth during the I965-I980 period, but for which the growth rate has decreased since the $1957-65$ period. Whether or not opportunities exist for minority entrepreneurs depends on such factors as: (I) the production capacity of existing firms; (2) the number of new firms to be developed during the coming decade; (3) new product development; (4) the ability of minority firms to reduce costs; (5) the relative sales promotion success of minority versus that of rival firms; (6) the availability of capital; and (7) the availability of trained minority managers and technicians.

\section{A. Technology-Intensive Industries}

A large number of higher growth opportunities exist in technology intensive industries. ${ }^{21}$ In the past, entry into these industries has been eased in many cases by government contract support, both in terms of direct support for research and

\footnotetext{
${ }^{20}$ It should be noted that the SIC code groupings may, in general, bring together different kinds of growth areas within one industrial code. Thus, further breakdowns of a given area may be necessary to find particularly desirable opportunities.

21 Technology intensive industries may be defined as those industries which have such characteristics as a much larger than average amount of their funds being spent on research and development, a significantly higher than average percentage of technologists in their employ, and a reliance on the production of new technology based products for their retention and expansion markets. Such industries would include: aircraft, scientific instruments, chemicals and electronics. See Natronar Science FounDation, Research aNd Devezopment in Industry, ig68 (rgjo).
} 
development expenses and through creation of a market for at least a limited number of the new products. The importance of government market creation has been dramatically demonstrated by the hundreds of new firms initiated in the Boston, Palo Alto, and Los Angeles areas since World War II. Research and development is a potentially profitable area, but it presents many problems, such as the need for substantial investments. In addition, these areas require technological expertise, managerial and entrepreneurial expertise, and sale promotion expertise.

Given these requirements, how can a minority enterprise launch itself into a highgrowth potential industry? The answer may lie in non-minority corporate support of minority spin-off firms, perhaps in conjunction with direct government grants or tax incentives. For example, a large manufacturing firm could set up a minority-run supplier to manufacture components for the manufacturer, or to provide a specialized service. One example of such a high technology spin-off is that established by the Bendix Corporation's Communications Division-Baltimore Electronic Associates, Inc. ${ }^{22}$

In a study of more than 200 new technology-based firms founded by former employees of the Massachusetts Institute of Technology research and development laboratories, the total proportion of failures found during the first five years of these spin-off firms was only 20 per cent, as compared with 80 per cent failure during the same period for all firms. ${ }^{23}$ In addition, the spin-off firms showed an exponential growth in sales during this same five-year period. During their preliminary stages, these firms were mainly preoccupied with government research and development, but tended to diversify rapidly into consumer markets. ${ }^{24}$

Potential minority businessmen seeking out areas of high growth might also look to the industries in which significant technological advances are expected, as there appears to be a correlation between research and development or technological research expenditures and long-run profits. ${ }^{25}$ Not only must minority businessmen enter fields in which subsidized research and development will occur, they must also enter fields which are already technology-intensive and in which expenditures on innovation will translate themselves into substantial profits during the coming decade. $^{26}$

One cannot predict with certainty which industries will experience significant

\footnotetext{
22 Bendix helped several of its minority employees establish a business to manufacture electrical components needed by Bendix. Originally the components were manufactured by the company, but it was thought that they could be produced less expensively by an outside source. Bendix has supplied management and technical assistance as well as help in purchasing for the new corporation, Baltimore Electronics Associates.

${ }^{23}$ Roberts, supra note 5, at 224-29.

24 Id, at 228 .

${ }^{25}$ See, e.g., U.S. Dep't of Commerce, Technological Innovation: Its Environment and ManageMent (I967); E. Mansfield, The Economics of Technological Change 43-98 (ig68); Freeman, Research and Development in Electronic Capital Goods, NAT'L InstituTe Rev., Nov., I965, at 40-9r.

${ }^{20} \mathrm{~S}$. Doctors, Federal R\&D Funding and Its Effects on Industrial Productivity, Jan., 1968 (unpublished paper prepared for the New England Research Application Center, University of Connecticut).
} 
technological changes, nor can one readily predit with absolute certainty where an innovative thought will occur. But the growth of investments in, and profits from, research and development expenditures appear to be closely correlated with government expenditures in any given area. ${ }^{2 \pi}$ While government expenditures for the 1960 's were concentrated in the areas of aerospace, electronics, and atomic energy, increased emphasis will be placed on research and development in such areas as medical research, education, sanitation, housing, and safety. ${ }^{28}$ If minorities are seeking high return investments, they must look toward these new areas of large government investment.

America has typically accepted technological advances with insufficient consideration for problems of physical health, sanity, and aesthetics such as the noisiness of airplanes and air pollution from automobiles. Thus, one higher growth business opportunity (in terms of government expenditures) will be the technology-intensive research and development industry which will deal with the problems created as a by-product of advanced technology.

\section{B. Discretionary Purchase Industries}

Another source of high growth opportunities is the discretionary purchase industry. Business opportunities may be said to lie in the areas of fad industries and intermediaries for labor-intensive production. The fad industry is one area of business opportunity which can show high growth but which does not necessarily involve a high level of technology. Increasing income and increasing leisure time will stimulate a tremendous increase in goods and services which will soon outgrow their stylishness. Despite the fact that employment for minorities may be cyclical or unpredictable and sporadic in these industries, the fad industires give unusual returns on capital. The toy industry is one example of business opportunity requiring relatively little capital outlay, but much innovation, extremely good sales promotion, and market appraisal.

An additional source of business opportunity is the area of businesses which provide special services as well as social services. The following areas of comparative strength may contribute to rewarding business opportunities by drawing on the strengths and knowledge of an ethnic or racial group: developing minority resources; capitalizing on ethnic or racial identities, experiences, and attitudes; providing (and researching) social services to minorities.

In the first area-resource development, minorities could act as developers and agents for talented minorities. For example, black recording stars, actresses, athletes, artists, and writers might also have black agents-provided adequate training, financing, and necessary contacts were available. The entrepreneurial aspect requires

\footnotetext{
${ }^{27}$ Nationat Planning Assoctation, Looxing Ahead, May, 1969, at il.

${ }^{28}$ See the discussion of new career opportunities in A. Peard \& F. Rtessman, New Cargers for the POoR chs. 3, 4, 5, 7 (1965).
} 
an aggressive sales promoter. Not only might this minority talent-public intermediary operate a highly successful business, but also this business venture would be one means of stopping the flow of minority talent to non-minority capitalists. For Indians and Mexican-Americans (many of whom are engaged in the making of handicraft, pottery, dolls, and carved items), an intermediary might exploit the rising market for custom goods by acting as a go-between for labor-intensive producers and retailers. Where possible, both types of intermediaries might also function in the final stages of trade or production.

Minorities operating in minority-identity fields might have a better understanding of minority needs than would other business firms. A chain of soul kitchens might be highly successful, especially if it combined good food with pleasant surroundings and served both minorities and non-minorities. Cosmetic, clothes, and hair products catering to minorities have, on the whole, met with widespread acceptance, although they are often so expensive that they are beyond the means of many potential customers. In an allied area, Latin minorities could investigate the development of import-export linkages with the increasingly important Latin American market; blacks could likewise involve themselves in African trade exchange.

An important minority comparative advantage includes the administration of social services in minority communities, since a minority individual, capitalizing on shared experiences, can better communicate with others of the same minority group. ${ }^{29}$ In the areas of mental health programs, drug and crime rehabilitation, and social welfare, a minority enterprise to administer social services, staffed by professionals in their respective social fields and with para-professional minority community residents, might have considerably more success and prove to be much less expensive than a similar governmental agency. ${ }^{30}$ Formal education and professional experience cannot overcome a lack of communications, distrust, and lack of common experience. Among groups with language problems, language training by bilingual minority members may capitalize upon a strategic weakness. In addition, a minority firm could do urban research into the quality of public services, and might well have an advantage over a similar non-minority firm.

\section{III}

\section{Government Creation and Encouragement of Market Development}

Since World War II, the federal government has become an important force in the creation of new markets in both the public and private sectors of the economy. ${ }^{\mathbf{3 1}}$

\footnotetext{
${ }^{20} 1 d$.

${ }^{30}$ Business and Defense Services Admintstration, Dep't of Commerce, Selected Industry Propiles: Detailed ANalysis of Minority Business Opportunities pt. $\mathrm{I}-\mathrm{V}$ (1969).

${ }^{31}$ State and local governments also purchase large quantities of goods and services, and create markets in many other ways, but this article will concentrate on the role of the federal government, leaving for
} 
A familiar example is the visible market created by the federal government in the aerospace area, which has amounted to several hundred billion dollars over the last ten years. ${ }^{32}$ But the government also creates market demand in many other ways, such as licensing, grants of insurance, and protection of monopoly status. Perhaps most important for minority enterprise development, the government can use its market creation power to provide numerous protected market areas so necessary for the development of most new enterprise, and the government can assume the role of the primary risk taker.

Of course, there are numerous other ways in which the government may create a protected market, as by the granting of a radio, television, or interstate commission carrier license. As previously noted, the government may also create substantial incentives for non-minority business to assist minority business with financial guarantees, subsidies, and grants. There is a variety of ways in which the federal government may use its powers to promote the development of minority enterprise. The following list is a brief survey of federal government market creation and development powers:

I. Risk Taker. The government has become the primary risk taker in many new technical areas such as radar, computer development, micro-electronics, and more recently, supersonic air transportation and artificial organs.

2. Direct Purchaser of Goods and Services. Many hundreds of new companies have been initiated and sustained through government contracts, including almost the entire aerospace industry.

3. Tax Incentives. ${ }^{33}$ The use of tax incentives has stimulated many different types of industrial development. The most widely publicized have been the various mineral depletion allowances and the investment tax credit. However, a large variety of taxes is commonly used by government at all levels for selective stimulation of business development.

4. Allocation of Scarce Resources. The issuance of licenses in regulated industries, such as air transport, communications, and interstate transport, have all provided substantial opportunities for business development. The grant of grazing, mineral, or timber rights on federal lands has also been quite important.

5. Insurance. The guarantee of investments by agencies, such as the Agency for International Development (AID), or the guarantee of loans by SBA or EDA, have been important in business development. New areas of proposed government

future works the exposition of the importance of the non-federal public sector for minority enterprise development. The ratio is about two to one in terms of present tax collection expenditures in favor of the federal government. I97o Dep'T of Commerce Survey of CuRrent Business.

${ }^{32}$ Aerospace research and development expenditures alone have totaled over \$roo billion during the last decade. See National. Sctence Foundation, Federal Funds for Research, Development, and Other Scientific Activities: Fiscal Years 1968 , rg69, and 1970 (1969).

${ }^{33}$ NACMBE has recommended the use of tax incentives for both direct non-minority business assistance to minority businesses and for training minority managers. 
TABLE VI

Government Spending bx Function rg67 Actual and i980 Projected

\begin{tabular}{|c|c|c|c|}
\hline \multirow[b]{2}{*}{ Program } & \multicolumn{2}{|c|}{$\begin{array}{l}\text { Total Government } \\
\text { Millions of Current } \$\end{array}$} & \multirow{2}{*}{$\begin{array}{c}\text { Average Annual } \\
\text { Growth } \%\end{array}$} \\
\hline & 1967 & 1980 & \\
\hline 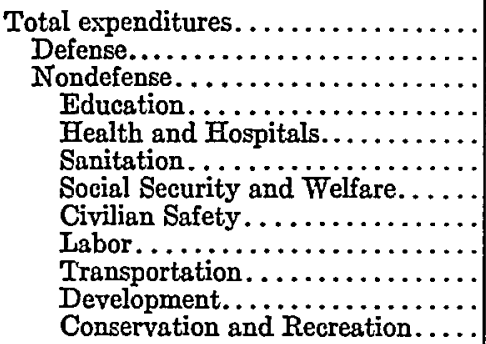 & $\begin{array}{r}241,253 \\
74,555 \\
166,698 \\
39,677 \\
8,547 \\
22,006 \\
40,994 \\
6,248 \\
1,087 \\
15,118 \\
713 \\
4,492\end{array}$ & $\begin{array}{r}587,164 \\
116,179 \\
470,985 \\
123,324 \\
35,087 \\
7,672 \\
103,683 \\
21,073 \\
5,176 \\
38,643 \\
11,052 \\
16,620\end{array}$ & $\begin{array}{r}7.08 \\
3.47 \\
8.32 \\
9.12 \\
11.48 \\
10.87 \\
7.40 \\
9.80 \\
12.75 \\
7.48 \\
23.47 \\
10.60\end{array}$ \\
\hline
\end{tabular}

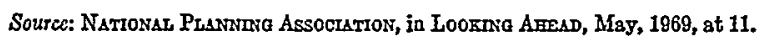

insurance include surety bonding for minority contractors and guarantee of equity investments in minority enterprise. ${ }^{34}$

6. Direct Loans. The government makes a significant amount of direct loan money available, particularly through SBA and EDA programs.

7. Tariffs and Quotas. The selective use of trade barriers has provided substantial opportunity for industrial development in a number of industries.

8. Supply of Capital Equipment. The government has often stimulated industrial development by allowing private firms to use or buy government-purchased equipment at reduced rates.

9. Subsidized Markets. The use of agricultural subsidies has provided a substantial impetus toward the creation of a highly efficient agriculture industry in this country.

This list indicates ways in which the federal government can use its powers to stimulate business development. However, minority businessmen have been almost totally excluded from such government programs. They have participated, if at all, only recently, and then primarily through the direct business loan. ${ }^{\mathbf{3 5}}$

At present, spending by federal, state, and local government is approximately onefifth of GNP, and is projected to increase during the period from I 967 to I980 by an

\footnotetext{
${ }^{84}$ OEO's newly initiated Opportunity Funding Corporation (OFC) will attempt to determine the efficacy of using federal government guarantees in a wide variety of applications to stimulate minority business and capital base development. See OfFice of Economic Opportunity, Opportunity Funding: An Economic Development Demonstration Program (i97o).

${ }^{35}$ A recent survey (by NACMBE) of SBA lending practices revealed that most loans to minority entrepreneurs were direct Equal Opportunity Loans (EOL) of $\$ 25,000$ each, while those to non-minority entrepreneurs were considerably larger, averaging $\$ 56,000$, and were guaranteed loans. The findings of the NACMBE indicated that minority businessmen have been almost totally excluded from most government business development programs.
} 
average annual rate of 7.08 per cent (Table VI). The greatest increase in government spending will be for housing and community development, both of which are concerned with fulfilling social needs. In general, government expenditures will exhibit increased focus upon housing, urban renewal, and other social benefits. Large increases in government expenditures for health and hospitals, conservation, and recreation will occur, while spending on national defense is expected to show the slowest growth rate of government spending. Thus, much government spending for the coming decade will complement high-growth industry in such areas as housing, education and health care. All are areas which will also assist in community development and over which the community should be able to exercise some control in the letting of contracts and grants. Thus, minority enterprise could be given a substantial portion of this new, higher growth business.

IV

\section{Demographic-Economic Trends and Business Opportunity}

Population growth or decline by geographic area, together with growth or decline in the work force and the number employed by occupation, suggests increases in manpower resources to take advantages of emerging business opportunities, and in manpower to provide purchasing power. Such population changes constitute significant changes in business opportunities. Four sets of interacting population movements affecting business opportunities and markets can be identified: (I) regional population trends; (2) the movement from rural to urban areas; (3) the movement of city population to the suburbs; and (4) an exchange of population according to race.

In general, the greatest rate of job and population growth has occurred along the rim of the country-moving along the West Coast, through the Southwest, and over to Florida. Higher-than-average growth increases also took place in the South and the West. The West will show the fastest gains in population and income, and the Southwest will show the fastest gains in employment. Florida (Southeast), Arizona (Southwest), Colorado (Mountains), California and Nevada (West) will be the states spearheading the growth of their respectives regions.

There has been a substantial decline of rural populations, and an increase in metropolitan areas. Rural population increased from 6r.4 million to 70.7 million in the 19 years from 1950 to 1969 . At the same time, metropolitan population increased from 89.2 million to 127.5 million people. ${ }^{36}$ Thus, while the rural (non-metropolitan) population was increasing by an annual average of .85 percent, the metropolitan population was increasing by 3.4 percent. $^{37}$

There is also a geographical concentration present among the states experiencing the fastest growth in services. Of the six states experiencing the greatest increase

\footnotetext{
${ }^{36}$ ig69 Bureat of the Census Current Population Reports.

${ }^{87} I d$.
} 
in service dollars spent (Maryland, South Carolina, Georgia, Florida, Alabama, and Hawaii, in that order), the fastest growing five are in the Southeast. Moreover, the service field, compared to retail trade, is a highly concentrated market geographically. The two leading states in spending for services are New York and California. These two states do more than one-third of the nation's service business, although they contain only one-fifth of its population. Illinois, Pennsylvania, Texas, and Ohio are the other national leaders in service dollars spent. All of these states contain substantial minority populations which could benefit from the growth of these service industries if an appropriate national strategy were developed now to channel substantial amounts of this new business to minority enterprise.

Given the above facts, it is obvious that business and job opportunities do not necessarily lie either in the northern United States or in the large cities. Business opportunity is growing more rapidly in the South (where the minority population is concentrated) than the national average. Medium-size cities may have better business growth opportunities than the inner city areas of the large cities.

Finally, there have been surprising increases in the population of small nonmetropolitan cities. In other words, the movement from the farms is not necessarily to the big city. This suggests that there are important nodules of business opportunity in cities of this smaller size, even in predominantly rural states.

It is important to realize that these population trends are not merely population movements, but are opportunity movements-opportunities for jobs and businessbecause they reflect an underlying growth of business and government in the fast-growing areas. This data gains importance when it is realized that the movement of the minority population is not in the direction of greatest opportunity. The movement of the minority population appears to be going in almost the opposite direction, although it must be cautioned that conclusions in this area are often impressionistic, since data on the movement of race is scarce. But an example which supports the hypothesis is New England. Its average annual employment growth rate during $196 \mathrm{r}-68$ was next to the lowest of the regions, 2.3 per cent ${ }^{38}$ but its increase in non-white male workers was the fastest in the nation; and this increase is expected to continue to grow at a rapid rate in the I970's.

During the past 25 years, the proportion of non-whites in the central city population has doubled, but it has declined in suburbia. In fact, between 1960 and Ig66, the Negro population in American central cities increased 22.9 per cent. It declined by I. 8 per cent for whites. ${ }^{39}$ Meanwhile, industry and manufacture have abandoned their old quarters, and have followed or even preceded the general movement of the more affluent population and business to the suburbs. The contrast is apparent: blacks go into the city while the jobs and businesses are moving away. ${ }^{40}$

\footnotetext{
38 x 969 Manpower Report of the President 35.

${ }^{80}$ U.S. Burean of the Census, Dep't of Commerce, Current Population Reports, Series p. 20, No. $18 \mathrm{I}$, Apr. 2r, 1969, at $\mathrm{I}$.

10 ig68 Manpower Report of the President 132.
} 
The South has increased in population, but the net growth is accounted for by the white population; the blacks have moved to the North and to the big cities. In the I950's, the South experienced a net loss of over I.4 million non-whites. Estimates place the net outmigration from the rural areas during the rg6o's at an average of more than three-quarters of a million persons a year. ${ }^{41}$

When total population movements are related to the population trends of minorities, it appears that there is increasing emigration of non-whites from higher-growth areas. This result suggests the need for a network to inform minorities of business opportunities based on demographic changes. At the very least, such information is needed to enable the minority entrepreneur to make realistic calculations about risks and opportunities. Rather than proposing a mass migration of minorities to higher-growth areas, it is proposed that some business opportunities for minorities be matched to specific areas of comparative advantage. Fortunately, there will exist in the r970's not only expanding horizons for business growth in geographic districts which are rapidly developing, but also opportunities in the inner city and the large metropolitan areas. These are often considered passé by non-minority entrepreneurs who think in terms of economic and business growth opportunities.

\section{V}

\section{Conclusion}

It is clear that greater opportunities for business development must be made available to minority entrepreneurs in order to provide one important component of total community development. It has not been suggested that business development, without other facets of development, such as greater education and health care opportunities, as well as greatly expanded job opportunities in non-minority business, is a panacea. But minority business development must provide a significant element in building the capital base in the minority community, in providing success models, and in providing opportunities for self-development.

Present programs for minority enterprise development are largely focused on short-term goals, such as providing quantities of equity and debt capital to numbers of minority enterprises, almost without regard to the growth potential of these enterprises. If the vast bulk of minority business is investment in low-growth, lowprofit potential businesses, then present programs may have the long-term impact of widening the gap between minority and non-minority businesses. It is, therefore, important that we attempt to make available to minority entrepreneurs the full range of business opportunities, with particular emphasis on higher growth potential opportunities.

It is possible to identify a number of areas of higher growth potential through a variety of indicators, such as projections of government spending, consumer de-

\footnotetext{
${ }^{21}$ Maitland \& Nebel, Rural to Urban Transition, Monmuly LABor Rev., June, 1968, at 28-32.
} 
mand, socio-economic patterns, and demographic projections. All of these changes represent new and often important higher growth potential opportunities. It is important to identify these areas, make this information available to minority entrepreneurs, and provide necessary financing, management and technical assistance. Such a program of business development must include a broadly based strategy designed to meet the many development deficiencies in the minority community. Such a comprehensive program has recently been proposed by the National Advisory Council on Minority Business Enterprise (NACMBE), which includes more than seventy-five recommendations for new and expanded programs in business opportunities, education, community development, and finance. ${ }^{42}$ Only a comprehensive program of this type will provide the human and technical resources needed to implement the business development strategy discussed in this paper.

The role of the federal government is crucial in the implementation of the proposed strategy. It may be desirable to delegate much of the actual implementation of the proposed strategy to the private sector, but only the government can provide the financial incentives, and create the markets needed to provide numbers of higher growth potential minority enterprise. The government can fill this latter role by: (I) the direct purchase of goods and services; (2) acting as a guarantor and subsidizer; (3) providing licenses; (4) acting as a risk taker; and (5) providing tax incentives or direct grants to motivate non-minority business involvement.

To summarize the proposed business opportunities analyzed, a comprehensive business opportunity strategy should concern itself with moving on all possible fronts. It must match community and individual resources with business opportunities. It must focus on higher-growth areas while performing a variety of community development functions, including employment, capital creation, and the production of needed goods and services. This mix of functions will provide a "staging area" for entrepreneurial development which can make a meaningful contribution to overall minority economic development.

\footnotetext{
62 See 1971 NACMBE Final Report (I97x).
} 